\title{
Phylogenetic Relationships of the Sweetpotato [Ipomoea batatas (L.) Lam.]
}

\author{
R.L. Jarret ${ }^{1}$, N. Gawe1 ${ }^{2}$, and A. Whittemore ${ }^{3}$ \\ U.S. Department of Agriculture, Agricultural Research Service, Southern Regional Plant \\ Introduction Station, 1109 Experiment Street, Griffin, GA 30223 \\ Additional index words. RFLP, evolution, germplasm, molecular systematic, related species
}

\begin{abstract}
Twenty-four accessions of Ipomoea, representing 13 species of section Batatas and the outgroup species $I$. gracilis and $I$. pes-caprae were analyzed for restriction fragment length polymorphisms. Polymorphisms were detected by probing Southern blots of restriction enzyme-digested genomic DNA with 20 low or moderate copy number sequences isolated from an $I$. batatas CV. Georgia Red genomic library. Data were analyzed cladistically and phenetically. Ipomoea trifida, I. tabascana, and collection K233 are, of the materials examined, the most closely related to sweetpotato (I. batatas). Ipomoea littoralis, the only Old World species in the section, is a sister species to $I$. tiliacea. Ipomoea littoralis, I. umbraticola, I. peruviana, I. cynanchifolia, and $I$. gracilis are shown to be diploid $(2 \mathrm{n}=2 \mathrm{x}=$ 30). In contrast, $I$. tabascana is tetraploid $(2 n=4 x=60)$. The intrasectional relationships of section Batatas species and the role of tetraploid related species in the evolution of the cultivated $I$. batatas are discussed.
\end{abstract}

Sweetpotato production worldwide exceeded $1.3 \times 10^{8} \mathrm{Mt}$ in 1989 (Food and Agriculture Organization, 1990), and the enormous potential of this crop as a carbohydrate source is widely recognized. To increase current production levels, new genes for resistance to various biotic and abiotic factors must be identified. Resistance to many important diseases and insects does not appear to be present in the I. batatas gene pool, which has focused attention on the use of exotic germplasm for sweetpotato improvement (Iwanaga, 1988; Orjeda et al., 1990). Nishiyama and Teramura (1962) were the first to use exotic germplasm in the form of the feral sweetpotato segregate K123 (Jones, 1967). Resistance to sweetpotato weevil (Cylas spp.), scab [Elsinoe batatas (Saw.) Viegas and Jenkins], and black rot (Ceratocystis fimbriata Ell. et Halst.) have been identified in plants reported as I. trifida and I. littoralis (Iwanaga, 1988). While the potential for the use of most section Batatas species in sweetpotato improvement has yet to be ascertained, other distantly related species contribute indirectly; I. setosa L. and I. carnea ssp. fistulosa Mart., ex Choisy are used as virus-indicator and flower-inducing rootstock, respectively. Increased awareness of the potential contribution of Ipomoea spp. to sweetpotato improvement is reflected in the recent efforts to collect and establish gene banks of these materials (de la Puente, 1988; Jarret et al., 1989).

Until recently, species boundaries in Ipomoea sect. Batatas were poorly understood. As a result, many species names have been misapplied in the taxonomic and agronomic literature, and different workers have often described similar and/or identical materials under different names, or material of distinct species under the same name. Austin (1978) provided a taxonomic revision of section Batatas based on the study of several hundred

Received for publication 7 Nov. 1991. Accepted for publication 6 Mar. 1992. We recognize the cooperation of the International Potato Center (CIP), Lima, Peru; J.A. McDonald, Univ. of Texas, Austin; D. Austin, Florida Atlantic Univ., Boca Raton; and Bob Johnson, QDPI, Indooroopilly, Australia, for providing plant material. R.L.J. also acknowledges the expert technical assistance of Lisa Dunbar. The cost of publishing this paper was defrayed in part by the payment of page charges. Under postal regulations, this paper therefore must be hereby marked advertisement solely to indicate this fact.

'To whom reprint requests should be addressed.

'Present address: The Missouri Botanical Gardens, P.O. Box 299, St. Louis, MO 63166.

${ }^{3}$ Present address U.S. Dept. of Agriculture, Agricultural Research Service, Western Cotton Research Lab., 4135 East Broadway Rd., Phoenix, AZ 85040. specimens, including type specimens of most of the species. He recognized 11 species and three other taxa believed to be of recent hybrid origin. This revision provides a soundly based outline of the taxonomy and nomenclature of Ipomoea sect. Batatas. Since 1978, three additional species have been recognized in the section [I. peruviana, formerly considered a synonym of I. batatas; I. umbraticola, formerly placed in sect. Eriospermum; and I. tabascana, a recently described endangered species from Mexico (Austin, 1988; Austin et al., 1991; McDonald and Austin, 1990)], while a fourth species (I. gracilis) has been removed (Austin, 1991).

One unresolved taxonomic problem that is particularly relevant to the understanding of sweetpotato evolution involves the relationship of $I$. batatas to a series of wild tetraploid plants that closely resemble cultivated sweetpotato in the structure of their leaves, flowers, and fruits. Mexican accessions of such tetraploids have been identified in the literature as I. gracilis (Jones, 1970), I. littoralis (Nishiyama et al., 1975), I. trifida (Shiotani and Kawase, 1987), I. batatas (Austin, 1988), or descendants of recent hybrids between cultivated sweetpotatoes and wild diploid weeds such as I. trifida (Austin, 1977). K233 is representative of one form of this latter group of plants.

To understand the origins of the cultivated sweetpotato, the relationships of the wild species with one another and with the cultivated sweetpotato must be more fully understood. However, little is known about the relationships of the species in this group. Austin (1988) has presented several phenetic analyses based on morphological characters. However, the morphological similarity of the species and the great plasticity of morphological characters in this group make it difficult to use morphological characters alone for phylogenetic reconstruction. We have, therefore, used restriction fragment length polymorphisms (RFLPs) for our phylogenetic study of this section. RFLPs can provide many genetic markers of high heritability. They have proven valuable for phylogenetic studies in several crop genera, including Lycopersicon (Miller and Tanksley, 1990), Brassica (Song et al., 1988), Solanum (Debener et al., 1990), Lens (Havey and Muehlbauer, 1989), and Glycine (Menacio et al., 1990).

\section{Plant material}

\section{Materials and Methods}

Plant material (Table 1) was, unless noted otherwise, obtained from the U.S. Sweetpotato Germplasm Repository (Jar- 
Table 1. Plant material used in this study.

\begin{tabular}{|c|c|c|c|}
\hline Species & Identifier & $\begin{array}{c}\text { Sample } \\
\text { no. }\end{array}$ & $\begin{array}{c}\text { Country of } \\
\text { origin }\end{array}$ \\
\hline Ipomoea batatas (L.) Lam. $(2 \mathrm{n}=90)$ & $\begin{array}{r}\text { PI538295 } \\
\text { PI538300 } \\
\text { Q27990 }\end{array}$ & $\begin{array}{l}97 \\
98 \\
99\end{array}$ & $\begin{array}{l}\text { Peru } \\
\text { Peru } \\
\text { New Guinea }\end{array}$ \\
\hline I. cordato-triloba Dennstedt & $\begin{array}{l}\text { PI518495 } \\
\text { PI540710 }\end{array}$ & $\begin{array}{l}14 \\
43\end{array}$ & $\begin{array}{l}\text { Mexico } \\
\text { Colombia }\end{array}$ \\
\hline I. cynanchifolia Meisn. & CIP460149z & 15 & Brazil \\
\hline 1. gracilis $\mathrm{R}$. Brown & PI538370 & 01 & Australia \\
\hline $\begin{array}{l}\text { I. lacunosa L. } \\
\text { I. littoralis Blume }\end{array}$ & $67.36^{y}$ & $\begin{array}{l}11 \\
22\end{array}$ & $\begin{array}{l}\text { United States } \\
\text { Australia }\end{array}$ \\
\hline I. peruviana O'Donell & CIP46026z & 19 & Peru \\
\hline I. pes-caprae (L.) R. Brown & PI518492 & 21 & Mexico \\
\hline I. ramosissima (Poir.) Choisy & $\begin{array}{l}\text { CIP460005z } \\
\text { CIP460036z }\end{array}$ & $\begin{array}{l}18 \\
41\end{array}$ & $\begin{array}{l}\text { Peru } \\
\text { Bolivia }\end{array}$ \\
\hline Ipomoea sp. & $\mathrm{K} 233^{\mathrm{y}}$ & 24 & Mexico \\
\hline I. tabascana McDonald \& Austin & PI518473 & 90 & Mexico \\
\hline I. tenuissima Choisy ${ }^{\mathbf{x}}$ & & 16 & United States \\
\hline I. tiliacea (Willd.) Choisy & DLP2925 & 12 & Mexico \\
\hline & PI530994 & 51 & Dominican Republic \\
\hline I. triloba $\mathrm{L}$. & PI540731 & 70 & Colombia \\
\hline & PI530998 & 53 & Dominican Republic \\
\hline I. trifida (H.B.K.) G. Don & PI540722 & 17 & Colombia \\
\hline & PI540724 & 80 & Colombia \\
\hline & PI543818 & 81 & Costa Rica \\
\hline I. umbraticola House ${ }^{w}$ & & 74 & Mexico \\
\hline
\end{tabular}

"Material obtained from J.A. McDonald, Univ. of Texas at Austin.

×From D.F. Austin, Florida Atlantic Univ., Boca Raton.

yFrom A. Jones, U.S. Dept. of Agriculture, Agricultural Research Service, 2875

Savannah Highway, Charleston, S.C.

'International Potato Center, Lima, Peru.

ret, 1989). Leaf tissue was collected from individual plants started from seed, frozen at $-135 \mathrm{C}$, freeze-dried, ground to a fine powder in liquid $\mathrm{N}$, and stored dessicated at $-20 \mathrm{C}$ until used. Accessions of I. batatas were obtained from an in vitro collection (Jarret, 1989), acclimated to soil in a quarantine greenhouse, and leaf tissue was harvested from individual plants. Leaf tissue of I. littoralis was harvested from a single accession of this species, collected in Queensland, Australia, in 1989, and maintained in quarantine in Griffin. Herbarium specimens of all plant material used in this study are available from the Southern Regional Plant Introduction Station.

\section{DNA isolation, digestion, electrophoresis, and blotting}

DNA was extracted from lyophilized leaf tissue following a procedure modified from that of Murray and Thompson (1980) and G. King (NPI, Salt Lake City, Utah, personal communication) as described by Gawel and Jarret (1991). Precipitated DNA was collected by centrifugation, resuspended in $400 \mu \mathrm{l}$ of $1 \mathrm{M} \mathrm{NaCl}$ with heat $(65 \mathrm{C}$ for $30 \mathrm{~min})$, and transferred to microtubes. Undissolved material was removed by centrifugation at $16,000 \times g$ for $2 \mathrm{~min}$, the supernatant was transferred to a new tube, and the DNA was ethanol-precipitated (Maniatis et al., 1982).

DNA ( 3 to $5 \mu \mathrm{g}$ ) was digested with 9 to $15 \mathrm{U}$ ( $\mathrm{U}=$ unit of enzyme activity) of Eco RI, Bam HI, or Msp I for $8 \mathrm{~h}$ at 37C. Fragments were separated on $0.8 \%$ agarose (BioRad) gels at 50 $\mathrm{V}$ for $20 \mathrm{~h}$ in TEA buffer. Following electrophoresis, the gels were denatured, neutralized, and Southern-blotted to nylon membrane following the membrane manufacturer's recommendations (BioTrans-ICN, Irvine, Calif.). DNA was bound to the membranes by exposure to ultraviolet radiation (Stratagene, La Jolla, Calif.).

\section{Library construction}

Total genomic DNA, isolated as described above from 'Georgia Red', was further purified on cesium chloride (Maniatis et al., 1982), ethanol-precipitated, and digested with Eco RI. Eco RIdigested genomic DNA was ligated into dephosphorylated Eco RIdigested pUC 18 and used to transform Escherichia coli strain LL308. Recombinant plasmids were screened on X-gal and their insert size determined. Plasmids, with insert sizes from 0.5 to $1.0 \mathrm{~kb}$, were cloned and their DNA isolated (Maniatis et al., 1982). Approximate copy number was determined by probing dot blots of plasmid DNA with ${ }^{32} \mathrm{P}$-labeled I. batatas cv. Georgia Red genomic DNA. Inserts were isolated from 20 plasmids, bearing low copy number sequences, on low melting-point agarose and were random primer-labeled (BRL) with $50 \mu \mathrm{Ci}(1 \mathrm{Ci}$ $=37 \mathrm{GBq}$ ) of ${ }^{32} \mathrm{P}-\mathrm{dCTP}$ (NEN, Dupont, Wilmington, Del.). Unincorporated nucleotides were removed by chromatography on Sephadex G50 (Maniatis et al., 1982).

\section{Hybridizations and autoradiography}

Membranes were prehybridized for 4 to $6 \mathrm{~h}$ in a prehybridization solution containing $6 \times \mathrm{SSC}, 0.001 \%$ sonicated denatured salmon sperm $(\mathrm{SS}), 5 \times$ Denhardt's solution, and $0.1 \%$ SDS at $65 \mathrm{C}$. Hybridizations were carried out in $6 \times \mathrm{SSC}, 0.001 \%$ SS, $0.1 \%$ SDS, and denatured labeled plasmid DNA. Membranes were hybridized overnight at $65 \mathrm{C}$ and washed successively in $2 \times \mathrm{SSC}, 0.1 \% \mathrm{SDS} ; 1 \times \mathrm{SSC}, 0.1 \% \mathrm{SDS}$; and $0.1 \times$ $\mathrm{SSC}, 0.1 \% \mathrm{SDS}$ for $30 \mathrm{~min}$ each at $65 \mathrm{C}$. Membranes were 
wrapped and exposed to X-ray film (Kodak X-Omat AR) in autoradiography cassettes with intensifying screens (Lighting Plus, Dupont).

\section{Root-tip chromosome counts}

Procedures for examination of somatic chromosomes were essentially as described by Jones and Kobayashi (1968). Fixed root tips were hydrolyzed in $0.2 \mathrm{~N} \mathrm{HCl}$ for $30 \mathrm{~min}$ at $65 \mathrm{C}$, allowed to cool for $30 \mathrm{~min}$ at room temperature, and stained with aceticorcein. Chromosomes were counted in a minimum of 10 cells per species examined.

\section{Data analysis}

Data were compiled into a 0-1 matrix and subjected to cladistic analysis by Wagner parsimony using the SWAP= GLOBAL and MULPARS $=$ ON options of PAUP version 2.4 (Swofford, 1985). To evaluate the strength of the resulting clades, the data were analyzed by the bootstrap method of Felsenstein (1986). Using the BOOT routine in PHYLIP (version 3.4), 100 bootstrap samples were generated by random resampling of the data set (Felsenstein, 1985) and separately subjected to Wagner parsimony analysis. Since bands visualized using the same probe may not be genetically independent (Gawel et al., 1992), they were linked using the FACTOR option of BOOT. The confidence level of each clade (the bootstrap statistic) is equal to the percentage of bootstrap trees in which that clade appears. The bootstrap values are plotted on the majority-rule consensus tree of these 100 bootstrap trees, which represents the topology with the strongest branch-by-branch statistical support. Following standard statistical methodology, we consider confidence levels of $95 \%$ or better to be significant. A detailed comparison of the PAUP and PHYLIP phylogenetic inference packages has been presented by Sanderson (1990).

For comparative purposes, a principal coordinate analysis (Gower, 1966) was performed using Jaccard's (1908) similarity index calculated using NTSYS-pc (Rholf, 1988).

\section{Results and Discussion}

Topologies of trees generated by PAUP and PHYLIP were identical. Wagner parsimony analysis of the 67-character data set yielded a single-most parsimonious cladogram 104 steps long (consistency index $=0.644$; Fig. 1). Bootstrap analysis showed that the statistical support for different clades varied from $29 \%$ to $100 \%$. Three clades showed significant (95\% or better) support (Fig. 1). These statistically significant divisions within the section are evident in the principal coordinate analysis (Fig. 2).

The unity of section Batatas, as currently defined, is well supported (bootstrap statistic $=96 \%$ ). The most strongly supported clade in the tree (bootstrap statistic $=100 \%$ ) consists of the cultivated sweetpotato, the tetraploid K233, and seven other species: I. cordato-triloba, I. cynanchifolia, I. lacunosa, I. tabascana, I. tenuissima, I. trifida, and I. triloba. This group contains all the closest relatives of the cultivated sweetpotato; all other taxa share fewer than half of the DNA fragments examined with I. batatas and must be considered more distantly related. Studies of the evolution of the sweetpotato should concentrate on a closer examination of the species in this group.

The closest relatives of cultivated sweetpotato seem to be the wild species I. trifida and I. tabascana, and the wild Mexican tetraploid represented by accession K233 (Fig. 2). The close relationship of these four taxa is strongly supported by our data (bootstrap statistic $=95 \%)($ Fig. 1). This result supports the

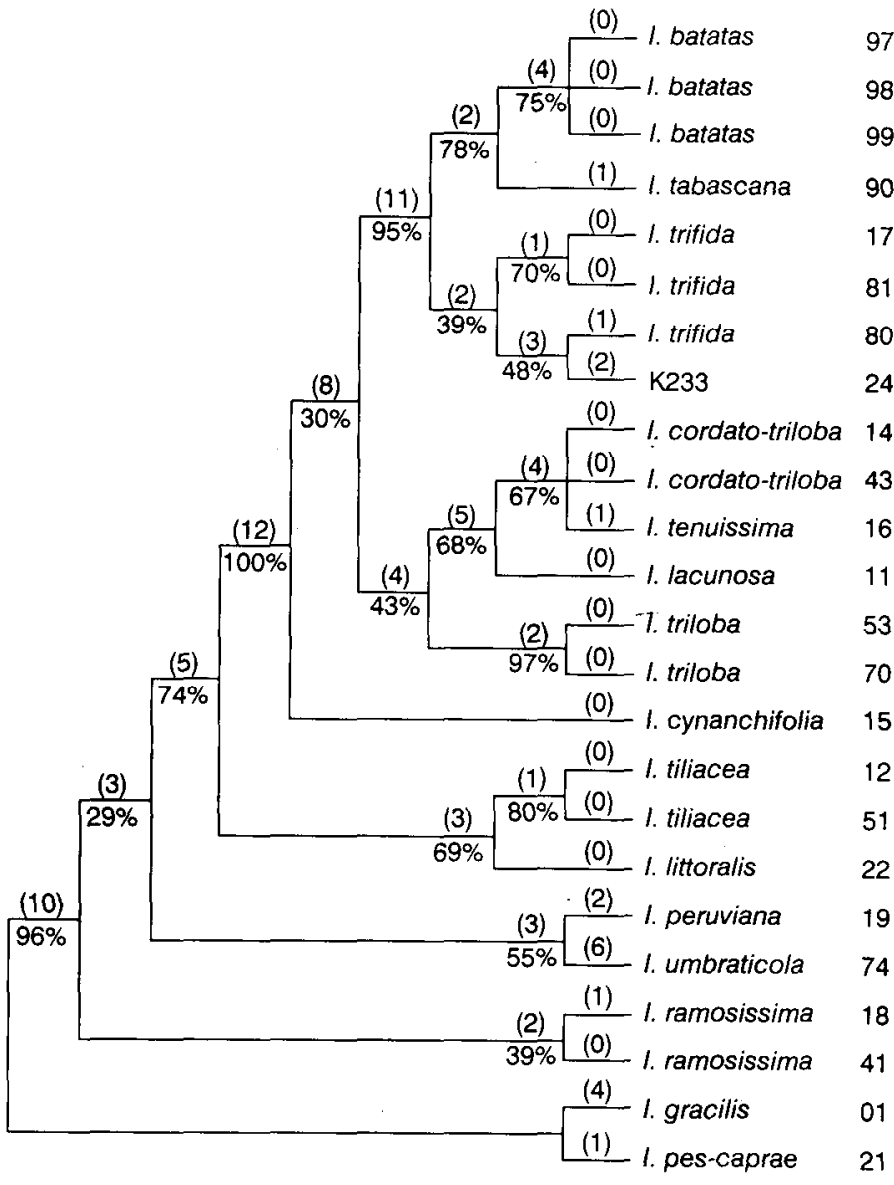

Fig. 1. RFLP-based cladogram illustrating phylogenetic relationships among Ipomoea spp. Numbers in parentheses above branches represent the number of shared derived characters unique to that branch. Numbers below each branch represent the bootstrap statistic (100 replications) supporting that branch. Sample numbers (Table 1) are listed to the right of the cladogram.

traditional view that I. trifida and the wild Mexican tetraploids are the most likely ancestors of cultivated sweetpotato (Austin, 1988) and indicates that the recently described species I. tabascana is also a very close relative of the crop plant. The species included in this group are classified genome B (Nishiyama et al., 1975). Other divisions within the section clearly transcend the boundaries of ploidy, compatibility, and genome type (Table 2).

The taxonomy of K233 and similar materials remains obscure. The literature contains numerous references to tetraploid accessions resembling I. batatas. These materials have been identified by various authors as I. gracilis (Jones, 1970; Martin and Jones, 1972; Ting et al., 1957), I. Iittoralis (Nishiyama et al., 1975), I. batatas (Austin, 1988; Jones, 1990; McDonald and Austin, 1990), or I. trifida (Shiotani and Kawase, 1987, 1989). Although principally collected in Veracruz, Mexico, tetraploid accessions resembling I. batatas have been reported from Cuba (Ting et al., 1957), the Virgin Islands (Jones, 1974), Columbia (Martin et al., 1974), Ecuador (Austin, 1982; Jones, 1990; Martin et al., 1974), and Honduras (F. de la Puente, personal communication). Martin et al. (1974) and Austin (1977) recognized that Mexican accessions 67.50, identified as I. gracilis, and K233, identified as I. littoralis by Nishiyama (1963) and more recently as I. trifida by Shiotanai and Kawase (1989), were identical. In our greenhouse studies, we have identified 


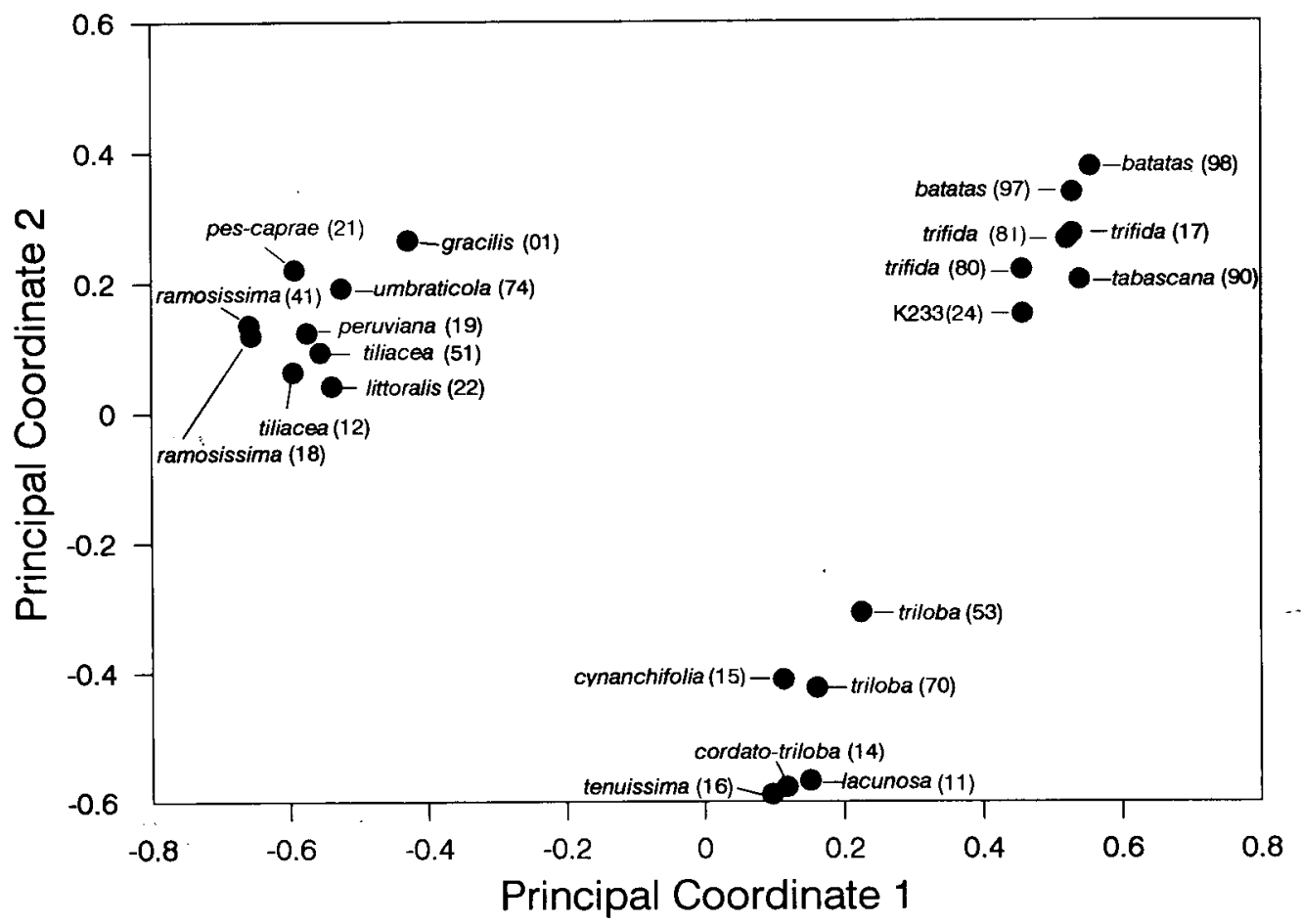

Fig. 2. A two-dimensional principal coordinate analysis of lpomoea spp.

Table 2. Ploidy, compatibility, and genome group ${ }^{2}$ of Ipomoea spp. and accessions. Chromosome counts, unless noted otherwise, are from Jones (1974).

\begin{tabular}{llcc}
\hline \hline Species & Ploidy & Self-compatible & Genome $^{\mathbf{z}}$ \\
\hline I. batatas & $2 \mathrm{n}=90$ & No & $\mathrm{B}$ \\
I. cordato-triloba & $2 \mathrm{n}=30$ & Yes & $\mathrm{A}$ \\
I. cynanchifolia & $2 \mathrm{n}=30^{\mathrm{y}}$ & Yes & $\mathrm{A}$ \\
I. gracilis & $2 \mathrm{n}=30^{\mathrm{y}}$ & No & $\mathrm{B}$ \\
I. lacunosa & $2 \mathrm{n}=30$ & Yes & $\mathrm{A}$ \\
I. littoralis & $2 \mathrm{n}=30^{\mathrm{y}}$ & No & $\mathrm{B}$ \\
I. peruviana & $2 \mathrm{n}=30^{\mathrm{y}}$ & No & $\mathrm{B}$ \\
I. pes-caprae & $2 \mathrm{n}=30$ & Yes & $\mathrm{A}$ \\
I. ramosissima & $2 \mathrm{n}=30$ & Yes & $\mathrm{A}$ \\
I. sp. (K233) & $2 \mathrm{n}=60^{\mathrm{z}}$ & No & $\mathrm{B}$ \\
I. tabascana & $2 \mathrm{n}=60^{\mathrm{y}}$ & No & $\mathrm{B}$ \\
I. tenuissima & $2 \mathrm{n}=30$ & Yes & $\mathrm{A}$ \\
I. tiliacea & $2 \mathrm{n}=60$ & No & $\mathrm{B}$ \\
I. trifida & $2 \mathrm{n}=30$ & No & $\mathrm{B}$ \\
I. triloba & $2 \mathrm{n}=30$ & Yes & $\mathrm{A}$ \\
I. umbraticola & $2 \mathrm{n}=30^{\mathrm{y}}$ & Yes & $\mathrm{A}$ \\
\hline
\end{tabular}

Nishiyama et al. (1975).

YThis paper.

accessions in our collection from Veracruz, Mexico, that are morphologically very similar to K233 and identical to accessions identified by McDonald as I. batatas var. apiculata. We suggest that $\mathrm{K} 233$ is a segregate of I. batatas var. apiculata, which explains its placement close to I. batatas. Chromosome counts (data not shown) indicate that I. batatas var. apiculata is tetraploid $(2 \mathrm{n}=4 \mathrm{x}=60)$.

A role for the various tetraploid forms of I. batatas in the evolution of the cultivated hexaploid sweetpotato is unclear. Tetraploid materials examined to date, including I. tabascana (Table 2), have not demonstrated an ability to form storage roots. However, this failure has not yet been systematically examined. According to Martin et al. (1974), roots of their tetraploid accessions, when cut from the parent plant, were able to sprout. We have not verified this characteristic with K233 or I. tabascana. Ipomoea trifida $(2 \mathrm{n}=2 \mathrm{x}=30)$ has a distinct perennial rooting habit (R.L.J. and A.W., unpublished data).

The hybrid members of the section, I. $\times$ leucantha Jacquin (Abel and Austin, 1973, 1980) and I. $\times$ grandifolia (Dammer) O'Donell (Austin, 1978), were not included in this analysis. Plant material of $I . \times$ grandifolia was not available. A hybrid origin for $I . \times$ grandifolia was proposed by Austin (1978). However, recent examination of newly acquired materials indicate that $I . \times$ grandifolia is a distinct species (D.F. Austin, personal communication) and should be included in future analyses.

Although less strongly supported by the bootstrap statistics, Figs. 1 and 2 illustrate a relationship between the North American species I. lacunosa, I. tenuissima, and I. cordato-triloba. Closely associated with these is I. triloba and, more distantly, I. cynanchifolia. Ipomoea triloba, endemic to the Caribbean and southern Florida, has also been suggested as a close relative to the sweetpotato (Austin, 1988). The South American species $I$. peruviana, I. tiliacea, and I. ramosissima; the Central American/Mexican species I. umbraticola, and the Old World species I. littoralis and I. gracilis appear to be more distantly related to I. batatas (Fig. 1).

Root-tip chromosome counts indicate that I. peruviana, $I$. umbraticola, I. cynanchifolia, I. littoralis, and I. gracilis are diploid, $2 \mathrm{n}=2 \mathrm{x}=30$ (Table 2).

Although the three major clades in Fig. 1 are well supported, others parts of the cladogram are less well resolved (bootstrap statistics < 80\%). These low bootstrap values reflect the relatively few unique character state changes supporting these clades. The level of within-species morphological and genetic (RFLP) variation in many of these species is high (A.W. and R.L.J., unpublished data on I. trifida; R.L.J., unpublished data on $I$. batatas). The topology of the cladogram is determined partly 
by the chance selection of particular genotypes from the complex array of genotypes that comprise each species. Further, natural hybridization is known to occur between species of this group (Abel and Austin, 1980; Austin, 1978). Introgressive gene flow between clades decreases the amount of genetic differentiation between species and weakens the historical association between the characters and the original phylogeny, thus decreasing the statistical confidence of the phylogenetic reconstruction. To improve the analysis, more individuals of these taxa, in combination with additional characters, are needed.

\section{Literature Cited}

Abel, W.E. and D.F. Austin. 1973. Natural hybridization in Ipomoea (Convolvulaceae). Amer. J. Bot. 60:33-34. (Abstr.)

Abel, W.E. and D.F. Austin. 1980. Introgressive hybridization between Ipomoea trichocarpa and I. lacunosa (Convolvulaceae). Bul. Torrey Bot. Club 108:231-239.

Austin, D.F. 1977. Hybrid polyploids in Ipomoea section batatas (Convolvulaceae). J. Hered. 68:259-260.

Austin, D.F. 1978. The Ipomoea Batatas complex I. Taxonomy. Bul. Torrey Bot. Club 105:114-129.

Austin, D.F. 1982. Convolvulaceae. vol. 15. In: G. Harling and B. Sparre (eds.). Flora of Ecuador. Swedish Res. Count., Stockholm.

Austin, D.F. 1988. The taxonomy, evolution and genetic diversity of sweet potatoes and related wild species, p. 27-60. In. P. Gregory (ed.). Exploration, maintenance, and utilization of sweet potato genetic resources. Intl. Potato Ctr., Lima, Peru.

Austin, D.F. 1991. Ipomoea littoralis (Convolvulaceae) -Taxonomy, distribution, and ethnobotany. Econ. Bot. 45:251-256.

Austin, D.F., F. de la Puent, and J. Contreras. 1991. Ipomoea tabascana, an endangered tropical species. Econ. Bot. 45:435.

de la Puente, F. 1988. Progress in explorations and collections of sweet potato genetic resources-The IBPGR/CIP project, p. 75-100. In: P. Gregory (ed.). Exploration, maintenance, and utilization of sweet potato genetic resources. Intl. Potato Ctr., Lima, Peru.

Debener, T., F. Salamini, and C. Gebhardt. 1990. Phylogeny of wild and cultivated Solanum species based on nuclear restriction fragment length polymorphisms (RFLPs). Theor. Appl. Genet. 79:360-368.

Food and Agriculture Organization. 1990. Production yearbook 1989, vol. 43. Food and Agriculture Organization of the United Nations, Rome.

Felsenstein, J. 1985. Confidence limits on phylogenies: An approach using the bootstrap. Evolution 39:783-791.

Felsenstein, J. 1986. PHYLIP (Phylogenetic Inference Package) version 2.9. Washington State Univ., Pullman.

Gawel, N.J. and R.L. Jarret. 1991. A modified CTAB DNA extraction procedure for Muss and Ipomoea. Plant Molec. Biol. Rptr. 9:262266.

Gawel, N.J., R.L. Jarret, and A. Whittemore. 1992. Restriction fragment length polymorphism (RFLP)-based phylogenetic analysis of Musa. Theor. Appl. Genet. (In press.)

Gower, J.C. 1966. Some distance properties of latent root and vector methods used in multivariate analysis. Biometrika 53:325-338.

Havey, M.J. and F.J. Muehlbauer. 1989. Variability for restriction fragment length phylogenies in lentil. Theor. Appl. Genet. 77:839843.

Iwanaga, M. 1988. Use of wild germplasm for sweet potato breeding, p. 199-210. In: P. Gregory (ed.). Exploration, maintenance, and utilization of sweet potato genetic resources. Intl. Potato Ctr., Lima, Peru.
Jaccard, P. 1908. Nouvelles recherches sur la distribution florale. Bul. Soc. Vaud. Sci. Natl. 44:223-270.

Jarret, R.L. 1989. A repository for sweet potato germplasm. HortScience 24:886.

Jarret, R.L., M. Spinks, G. Lovell, and A.G. Gillaspie. 1989. The S-9 Plant Gennplasm Repository. Diversity 6:23-24.

Jones, A. 1967. Should Nishiyama's K123 (Ipomoea trifida) be designated I. batatas? Econ. Bot. 21:163-166.

Jones, A. 1970. Asynapsis in Ipomoea gracilis. J. Hered. 61:151-152. Jones, A. 1974. Chromosome numbers in the genus lpomoea. J. Hered. 55:216-219.

Jones, A. 1990. Unreduced pollen in a wild tetraploid relative of sweetpotato. J. Amer. Soc. Hort. Sci. 115:512-516.

Jones, A. and M. Kobayashi. 1968. Derived polyploids of section Batatas genus Ipomoea. Proc. Amer. Soc. Hort. Sci. 93:497-501.

Maniatis, T., E.F. Fritsch, and J. Sambrook. 1982. Molecular cloning: A laboratory manual. Cold Spring Harbor Laboratory, N.Y.

Martin, F.W. 1968. The system of self-incompatibility in Ipomoea. J. Hered. 59:262-267.

Martin, F. and A. Jones. 1972. The species of Ipomoea related to sweet potato. Econ. Bot. 26:201-215.

Martin, F.W., A. Jones, and R.M. Ruberte. 1974. A wild Ipomoea closely related to the sweet potato. Econ. Bot. 28:287-292.

McDonald, J.A. and D.F. Austin. 1990. Changes and additions in Ipomoea section Batatas (Convolvulaceae). Brittonia 42:116-120.

Menacio, D.I., A.G. Hepburn, and T. Hymowitz. 1990. Restriction fragment length polymorphisms (RFLPs) of wild perennial relatives of soybean. Theor. Appl. Genet. 79:235-240.

Miller, J.C. and S.D. Tanksley. 1990. RFLP analysis of phylogenetic relationships and genetic variation in the genus Lycopersicon. Theor. Appl. Genet. 80:437-448.

Murray, M.G. and W.F. Thompson. 1980. Rapid isolation of high molecular-weight plant DNA. Nucleic Acids Res. 8:4321-4325.

Nishiyama, I. 1963. The origin of the sweet potato plant, p. 119-128. In: J. Barrau (ed.). Plants and the Pacific migrations of Pacific peoples. Proc. 10th Pacific Sci. Conf., Honolulu.

Nishiyama, I. and T. Teramura. 1962. Mexican wild form of sweetpotato. Econ. Bot. 16:304-314.

Nishiyama, I., T. Niyazaki, and S. Sakamoto. 1975. Evolutionary autoploidy in the sweet potato (Ipomoea batatas (L.) Lam.) and its progenitors. Euphytica 24:197-208.

Orjeda, G., R. Freyre, and M. Iwanaga. 1990. Production of $2 \mathrm{~N}$ pollen in diploid Ipomoea trifida, a putative wild ancestor of sweet potato. J. Hered. 81:462-467.

Rholf, F.J. 1988. NTSYS-pc, numerical taxonomy and multivariate analysis system. Exeter Publ., New York.

Sanderson, M.J. 1990. Flexible phylogeny reconstruction: A review of phylogenetic inference packages using parsimony. Syst. Zool. 39:414-420.

Shiotani, I. and T. Kawase. 1987. Synthetic hexaploids derived from wild species related to sweet potato. Jpn. J. Breeding 37:367-376.

Shiotani, I. and T. Kawase. 1989. Genomic structure of the sweet potato and hexaploids in Ipomoea trifida (H.B.K.) Don. Jpn. J. Breeding 39:57-66.

Song, K.M., T.C. Osborn, and P.H. Williams. 1988. Brassica taxonomy based on nuclear restriction fragment length polymorphisms (RFLPs). Theor. Appl. Genet. 76:593-600.

Swofford, D.L. 1985. PAUP-Phylogenetic analysis using parsimony, version 4.2. Ill. Natural History Survey, Champaign.

Ting, Y.C., A.E. Kehr, and J.C. Miller. 1957. A cytological study of the sweet potato plant Ipomoea batatas (L.) Lam. and its related species. Amer. Naturalist 91:197-203. 